\title{
Detection Methods for Seed Borne Pathogens
}

\author{
Pooja Upadhyay ${ }^{1}$ and Samar Pal Singh ${ }^{2 *}$ \\ ${ }^{1}$ G.B. Pant Universty of Agriculture and Technology, Pantnagar-263 145, India \\ ${ }^{2}$ Krishi Vigyan Kendra, New Delhi-73, India
}

*Corresponding author

\section{A B S T R A C T}

Keywords

Seed Borne

Pathogens, PCR

based molecular

method

Article Info

Accepted:

04 February 2019

Available Online:

10 March 2019
Seed is the custodian of the genetic, potential of any cultivar and determines the limits of productivity in any cropping system. So awareness for seed health has increased among the growers, traders and consumers in recent years. A seed-borne inoculum not only secures the presence of a virulent strain of the pathogen along the seed but also favors the earliest possible establishment of the infection in seedlings along with possible threat of introduction of new physiological races/stains with seed. With the guidelines of ISTA a number of detection methods starting from visual observation to PCR based molecular methods are being used for the detection of fungi, bacteria, virus and other seed borne pathogen. As detection of seed borne pathogens is the first line approach in managing seed borne diseases of plants so new methods of detection along with seed health testing approach are necessary to avoid the constraints in seed production and to reduce the cost for disease management in agriculture.

\section{Introduction}

Seed is the custodian of the genetic, potential of the cultivar thus the quality of the seed determines the limits of productivity to be realized in any given cropping system. In recent years, the awareness for seed health has increased among the growers, traders and consumers especially post GATT era and with the emergence of WTO, seed health has assumed the global concern. Various examples of impact of seed borne diseases have drawn attention of seed pathologists e.g. Karnal bunt of wheat caused by Tilletia indica is not acceptable for human consumption due to presence of a tri-methylamine chemical is which is responsible for fishy odour, perceptible discolouration and inability to consume. In ergot disease of pearl millet, sorghum and triticale caused by Claviceps spp. presence of mycotoxin ergotin makes it toxic for human and animal consumption. In India during early 1956 in south-western parts ergot disease in sorghum and pearl millet appeared in epidemic form. Marathawada region of Maharashtra is identified as endemic area for sunflower downy mildew disease. Wheat bunt (Karnal bunt) and now rice bunt are of the major concern in Punjab, Haryana and adjoining parts of Uttar Pradesh. Scab of potato appears in severe form in Indo gangetic region. Ear cockle is endemic in 
certain north-west parts of Madhya Pradesh and parts of Rajasthan. The outbreaks made seed people to rethink on the use of clean seeds.

\section{Importance of seed health and seed health testing}

According to ISTA, Zurich, Switzerland, "Seed health refers primarily to the presence or absence of disease causing organisms such as fungi, bacterial and viruses, and animal pests such as nematodes and insects but physiological conditions such as trace element deficiency may be involved". Seed-borne inoculum secures the presence of a virulent strain of the pathogen along the seed. In this way the presence of a pathogen with the seed favors the earliest possible establishment of the infection in seedlings. Un-infested soil may be inoculated by the introduction of infected seeds hence subsequent crop raised from healthy seed may in turn be infected from the soil. New physiological races/strains may be introduced with the seed so that varieties resistant to endemic races of the organism become affected. It is important to know the health status of seed lots and keeping its quality under storage and consequently it's planting value.

\section{Earlier concept and problems in seed pathology}

Earlier concept of seed pathology referred almost solely to the detection of microorganisms in or on seeds, a practice that had been conducted already for a century or more. Pathological aspects of seeds initially were considered almost entirely within the context of the seed-testing laboratory. The incorporation of epidemiological concepts and management considerations along with seed testing is taking place in the seed production field, the postharvest environment, and the crop production field were considered important part in relation to seed pathology
(Baker, 1972, Agarwal and Sinclair, 1997). Because of these ideas seed pathology now occupies a broader scope of research and practice; it can be described as "The study and management of diseases affecting seed production and utilization, as well as disease management practices applied to seeds". This broader concept recognizes the inclusion of diseases that affect seed production (but are not necessarily seed-borne) under the umbrella of seed pathology. Beside this standardisation, unification and improvement of diagnostic methods were the first emerging problems when seed pathologists of different laboratories and countries compared their own data. After some meetings held in different parts of Europe, the International Seed Testing Association (ISTA) was founded during the Congress held in Cambridge in 1924. The technical committee "Investigations of Genuineness of Variety and of Plant Diseases" was established, and subsequently the Plant Disease Committee (at present Seed Health Committee), became active in the improvement of seed health testing. The main purposes of the Committee have been the standardisation and improvement of methods to be applied to the seed. Such an activity was strongly stimulated by the programme established in 1957, together with the organisation of workshops concerning emerging problems in different parts of the world. By the efforts of As a result of ISTA activities, manuals and papers concerning seed health methods were published. During the activities carried out in the past, some classic diagnostic methods have been standardised and have been applied to seed samples for a long time.

\section{Traditional methods of seed testing}

Primarily researchers focused mainly on detection of fungus on seeds but later detection of virus and bacteria was also came into existence with increased knowledge of pathogen transmission in seeds. These 
traditional methodologies included following methods.

\section{Visual inspection of dry seed}

Symptoms of fungal infection such as fungal structures as sclerotia, encrusted mycelium or discoloration, pigmentation etc. are detected my naked eyes by the use of optical lenses, stereomicroscopes (purple stain of soybean, ergot of cereals black point of wheat etc. (De Tempe and Binnerts, 1979) e.g. ear rot or tundu disease of wheat seeds which is caused by nematode Anguina tritici (Steinbuch) Chitwood. in detected by visual observation of the black galls. Along with this discolouration of seed and morphological abnormalities are analyzed by visual observation of seeds.

\section{Microscopic examination}

Infected seeds under a stereomicroscope reveal the presence of spores on seed surfaces, e.g. Wheat seeds infected with Karnal bunt are observed under stereomicroscope.

\section{Washing test}

A conventional method of detecting pathogen inoculum located on the seed surface (oospores of downy mildew fungi, teliospores of smuts and bunts, etc.) is detected.

\section{Seed soak method}

Seeds infected with bunt disease or tundu disease is detected by using the $\mathrm{NaOH}$ soak method (Agarwal and Verma, 1983; Agarwal and Srivastava, 1985).

\section{Incubation method}

Incubation method is the most popular and frequently used method for the detection of a great number of seed-transmitted pathogens
(Alternaria spp., Drechslera spp., Fusarium spp., Stemphylium spp. etc.) In this method seeds are kept in incubation for a certain period in a certain medium for confirmation of the presence of pathogen (De Tempe, 1961; De Tempe and Binnerts, 1979). After the incubation period, fungi developed on each seed are examined by mean of stereomicroscope or/and compound microscope for the determination of the morphological characters of conidia, spores, etc.

\section{Growing on test (Seedling symptom test)}

Seeds are sown in greenhouse in suitable substrates (brickstone, sand or other sterile substrate, agar tubes, etc.) in different environmental conditions. This method is particularly useful when seedlings show symptoms in a short time.

\section{Staining test}

In particular situations, when the inoculum is located in the internal tissues of the seed and it is impossible to detect the fungi in a reasonable time with the above mentioned methods, some staining compounds specific for fungal hyphae (i.e. trypan blue, aniline blue, rose bengale etc.) are used for pathogen detection by staining method.

\section{Embryo count}

When the inoculum of a fungus is located in the embryo eg. in Ustilago nuda and $U$. tritici, embryo count method is used for separation embryo from the rest of the seed for microscope observations (Rennie, 1982).

\section{Immunodiagnostic methods}

Under immunodiagnostic methods, antibody methods such as micro-titre enzyme linked immune sorbant assay (ELISA), immune fluorescence staining test (IFST), seed 
immune blot binding assay (SIBA), dyed latex bead agglutination test and immune dipstick assay etc. have been used for pathogen detection in seed pathology. The immunodiagnostic assays for field use are inexpensive, rapid and do not require highly trained personnel.

\section{Micro-titre ELISA}

It has been a widely used method for early detection of Karnal bunt pathogen in the host when the infection levels are very low (Varshney, 1999). In this way seed pathology involves research aspect for more innovative approach which mainly focuses on these areas:

Research innovations in the detection of seedborne pathogens.

Advances in the development and use of seed treatments.

Progress toward standardization of phytosanitary regulations, especially in relation to seed health testing.

\section{Research innovations in seed pathology:}

Seed pathology research is typically considered to emphasize detection methods for seedborne pathogens and a number of innovations are taking place in this area now a days. The invention of polymerase chain reaction (PCR) revolutionized biological diagnostics, opening a new era in medical and veterinary pathogen detection as well as a potential for detection of pathogens in seed (Hensen, 1993, Pearce, 1998). Since that time, many PCR-based detection methods have been developed and applied to seed borne pathogens. Agarwal (2006) which include the polymerase chain reaction (PCR) and other DNA-based detection systems such as BioPCR, Immuno-magnetic Separation and PCR (IMS-PCR), Magnetic Capture Hybridization and PCR (MCH-PCR), real time PCR and DNA chip technology (microarrays). A brief description of following innovative detection methods is as follows.

\section{PCR based detection method}

PCR consists in vitro enzymatic amplification of an initial quantity of target DNA (Erlich $e t$ al., 1988) and, due to its specificity, speed and sensitivity; it has been used in the diagnosis of many seed borne pathogens. But high capital costs and technical expertise for establishing PCR capabilities is major constraint in PCR based detection technique.

While second major obstacle in successful implication of this method is false negatives (inhibition of PCR reaction by various compounds contained in seeds) and false positives (amplification of DNA from non viable cells) which restricts the accurate detection of the pathogen. Along with this its incapability in distinguishing between viable and non viable cells is also one of major constraint of this method.

\section{Bio-PCR}

Bio-PCR consists of the preventive growth of target pathogens on selective media and their selective increase, relative to non-target microorganisms, followed by DNA extraction and amplification by PCR (Schaad et al., 1995).

Different plant pathogens eg. Ex. Pseudomonas syringae pv. Phaseolicola, Acidovorax avenae spp. Avenae, Xanthomonas oryzae pv. Oryzae can be detected by Bio-PCR method.

Major disadvantage of this method is that it cannot be used for obligate pathogens as they cannot be cultured in artificial media. Secondly this method requires a well defined selective media for pathogen culturing which makes it time consuming procedure. 


\section{IMS-PCR}

In this method, small magnetic beads, coated with antibodies for a specific microorganism, are able to selectively bind target cells from suspensions containing a mixture of cells (Olsvik et al., 1994; Walcott and Gitaitis 2000). Captured cells can then be incubated on selective media in order to increase the amount of the target pathogen or, alternatively, they could be used directly for DNA extraction and PCR run. Though IMSPCR is more efficient and sensitive than conventional PCR but it relies on specific antibodies which may not be always available. More-over, due to the difficulty of beads for capturing cells of filamentous fungi, it can be successfully used for bacteria only.

\section{MCH-PCR}

In this method magnetic beads coated with single stranded DNA probes are used to capture DNA fragments which will be used for PCR. This technique has been used to detect fungi, bacteria and viruses in materials containing PCR inhibitory compounds (Jacobsen 1995). This technique is rapid and able to overcome the inhibitory effects of seed compounds but it also can not distinguish between viable and non viable cells.

\section{Real time PCR}

This method consists of coupling DNA amplification with fluorescence substances which can be easily measured, giving an indirect measurement of DNA amplification. Real time PCR has the possibility of quantifying a certain pathogen in a seed lot. Beside this, there is no need for electrophoresis as all the process is completed inside the same machine. Though it is efficient and rapid in comparison to conventional PCR but still quite expensive.

\section{DNA chip technology}

In DNA chip technology (Lemieux et al., 1998), a large number of oligo nucleotides are positioned on a small glass or silica surface (chip). Target pathogen DNA is digested into small fragments which are labelled with fluorescent markers and hybridized with oligo nucleotides on the DNA chip. The presence of fluorescence indicates the presence of the pathogen of interest is present in the chip.

DNA chip technology has a possibility of detecting more pathogens at the same time in a low completion time.

Nucleic acid based methods have certain advantages over conventional methods especially in early diagnosis of seedborne fungal pathogens as often, infected seeds appear symptomless. Seed diagnosis can avoid uncontrolled propagation of pathogens through long-distance exchange of such material. This will prevent economic losses and unnecessary use of fungicides, so reducing costs and the introduction of toxic substances into the environment. Traditional techniques for detection of seed borne fungi are based on incubation and grow-out methods are simple in application but they are time-consuming, require mycological skills, and are sometimes not sensitive enough to low levels of seed infection. So new identification techniques, based on DNA analysis, can be very efficient due to high sensitivity and specificity.

\section{Future prospect}

DNA based tests represent an important resource for the future of seed health testing. It is desirable that more advanced methods will be developed to detect the presence of vital pathogen cells in seeds or to identify and characterize, at intra specific level, the pathogens extracted from seeds. However, 
before the routine use of innovative molecular techniques, it is necessary to compare the results obtained on seed sub-samples in different laboratories. The integration of different methods (traditional and innovative) depending on the particular features of each host-pathogen combination could be conveniently used in order to select only for the advantages, avoiding the limitations of each method.

\section{References}

Agarwal VK, Sinclair JB. 1997. Principles of Seed Pathology. $2^{\text {nd }}$ ed. Boca Raton, FL: CRC Press. 539 pp.

Agarwal VK, Srivastava KD (1985) $\mathrm{NaOH}$ seed soak method for routine examination of rice seed lots for rice bunt. Seed Res., 13: 159-161.

Agarwal VK, Verma HS (1983) A simple technique for detection of Karnal bunt infection in wheat seed samples. Seed Res 11: $110-112$

Baker KF, TT Kozlowski (1972). Seed pathology. In ed., Seed Biology, 2: 317-416. New York: Academic Press. 447 pp.

Block CC, McGee DC, Hill JH. (1999). Relationship between late season Stewart's bacterial wilt and seed infection in maize. Plant Dis. 83:527-30

De Tempe J., (1961): Routine methods for determining the health condition of seeds in the seed testing station. Proc. Int. Seed Test. Assoc. 26: 27-60.

De Tempe J., Binnerts J., (1979): Introduction to methods of seed health testing. Seed Sci. Technol. 7: 601-636.

De Tempe J., Binnerts J., (1979): Introduction to methods of seed health testing. Seed Sci. Technol. 7: 601-636.

Erlich H.A., Gelfand D.H., Saiki R.K., (1988): Specific DNA amplification. Nature (Lond.) 331: 461-462.
Heid C.A., Stevens J., Liak K.J., Williams P.M., (1996): Real time PCR. Genome Res. 6: 986-994.

Jacobsen C.S., (1995): Microscale detection of specific bacterial DNA in soil with a magnetic capture hybridization and PCR amplification assay. Appl. Environ. Microbiol. 61: 3347-3352

Lemieux B., Aharomi A., Schena M., (1998): Overview of DNA chip technology. Mol. Breed. 4: 277-289.

Olsvik O., Popovic T., Skjerve E., Cudjoe K.S., Hornes E., Ugelstand J., Uhlen M., (1994): Magnetic sepa-ration techniques in diagnostic microbiology. Clin. Microbiol. Rev. 7: 43-54.

Palmer LT, MacDonald D, Kommedahl T. (1967). The ecological relationship of Fusarium moniliforme to Pratylenchus scribneri in seedling blight of corn. Phytopathology 57:825

Pearce DA. DK Arora, CA Reddy, RP Elander.(1998). PCR as a tool for the investigation of seedborne disease. In Applications of PCR in Mycology, pp. 309-324. New York: CAB Internatl.

Rennie W.J., (1982): Barley. Loose smut. In: ISTA handbook on seed health testing. Working sheet n. 25. ISTA, Zürich

Rennie WJ (1982) Wheat Loose Smut. ISTA Handbook on Seed Health Testing, Section 2, Working Sheet No. 48,

Schaad N.W., Cheong S.S., Tamaki S., Hatzilouka E., Panopoulos N.J., (1995): A combined biological and enzymatic amplification (BIO-PCR) technique to detect Pseudomonas syringae pv. phaseolicola in bean seed extract. Phytopathology 85: 243-248.

Walcott R.R., Gitaitis R.D., (2000): Detection of Acidovorax avenae subsp. citrulli in watermelon seed using immunomagnetic separation and the polymerase chain reaction. Plant Dis. 84: 470-474.

\section{How to cite this article:}

Pooja Upadhyay and Samar Pal Singh. 2019. Detection Methods for Seed Borne Pathogens. Int.J.Curr.Microbiol.App.Sci. 8(03): 318-323. doi: https://doi.org/10.20546/ijcmas.2019.803.039 